\title{
Subsurface urban heat island and its effects on horizontal ground-source heat pump potential under climate change
}

Article

Accepted Version

Luo, Z. and Christina, A. (2015) Subsurface urban heat island and its effects on horizontal ground-source heat pump potential under climate change. Applied Thermal Engineering, 90. pp. 530-537. ISSN 1359-4311 doi:

https://doi.org/10.1016/j.applthermaleng.2015.07.025

Available at https://centaur.reading.ac.uk/40731/

It is advisable to refer to the publisher's version if you intend to cite from the work. See Guidance on citing.

Published version at: http://www.sciencedirect.com/science/article/pii/S1359431115006900

To link to this article DOI: http://dx.doi.org/10.1016/j.applthermaleng.2015.07.025

Publisher: Elsevier

All outputs in CentAUR are protected by Intellectual Property Rights law, including copyright law. Copyright and IPR is retained by the creators or other copyright holders. Terms and conditions for use of this material are defined in the End User Agreement.

www.reading.ac.uk/centaur 
Central Archive at the University of Reading

Reading's research outputs online 
2

3 Subsurface urban heat island and its effects on horizontal 4 ground-source heat pump potential under climate change 5 6

E-mail: z.luo@reading.ac.uk

Zhiwen Luo ${ }^{1,2,3^{*}}$, Christina Asproudi 2

1. Key Laboratory of the Three Gorges Reservoir Region's Eco-Environment, Ministry of Education, Chongqing University, Chongqing, China

2. School of Construction Management and Engineering, University of Reading, Whiteknight campus, United Kingdom

3. Walker Institute, University of Reading, Whiteknight campus, United Kingdom

Correspondence: Dr Zhiwen Luo

School of Construction Management and Engineering, University of Reading, 212

Engineering Building, Whiteknights, Reading, RG6 6AY

Phone: 01183785219

30 


\section{Abstract:}

34 Recent urban air temperature increase is attributable to the climate change and heat 35 island effects due to urbanization. This combined effects of urbanization and global 36 warming can penetrate into the underground and elevate the subsurface temperature. 37 In the present study, over-100 years measurements of subsurface temperature at a 38 remote rural site were analysed, and an increasing rate of $0.17^{\circ} \mathrm{C}$ per decade at soil 39 depth of $30 \mathrm{~cm}$ due to climate change was identified in the UK, but the subsurface 40 warming in an urban site showed a much higher rate of $0.85^{\circ} \mathrm{C}$ per decade at a $30 \mathrm{~cm}$ 41 depth and $1.18^{\circ} \mathrm{C}$ per decade at $100 \mathrm{~cm}$. The subsurface urban heat island (SUHI) 42 intensity obtained at the paired urban-rural stations in London showed an unique 'U43 shape', i.e. lowest in summer and highest during winter. The maximum SUHII is $3.5^{\circ} \mathrm{C}$ at 6:00 $\mathrm{AM}$ in December, and the minimum UHII is $0.2^{\circ} \mathrm{C}$ at $18: 00 \mathrm{PM}$ in July. Finally, the effects of SUHI on the energy efficiency of the horizontal ground source heat pump (GSHP) were determined. Provided the same heat pump used, the installation at an urban site will maintain an overall higher COP compared with that at a rural site in all seasons, but the highest COP improvement can be achieved in winter.

Keywords: subsurface, urban heat island, climate change, ground source heat pump, urbanization 


\section{Introduction}

Urban heat island (UHI) refers to a higher urban temperature in the urban centre compared to the surrounding rural areas, which is mainly the consequence of rapid urbanization by changing permeable forest and agriculture landscapes into sealed and water-proof man-made urban texture. A significant urban warming can lead to: 1) deterioration of the human thermal comfort especially during hot summer nights in temperate climate; 2) increase of the building energy consumption by turning on airconditioning for summer cooling; and 3) exacerbation of carbon emissions from higher electricity demand and energy expenditure. According to [1], there are basically three types of UHI, i.e., urban air heat island, urban surface heat island, and urban subsurface heat island. The former two types are well investigated with different methodologies; however, the latter subsurface urban heat island (SUHI) is much less addressed. As a matter of fact, the subsurface soil temperature is a crucial variable to control the ecosystem's biological and chemical processes such as soil respiration, thawing of permafrost, microbial decomposition and groundwater flow [2]. It also has a strong impact on the underground infrastructure especially in an urban context.

The subsurface soil temperature is determined by the combined effects of ground heat flux, the heat flow from the Earth's interior, the soil thermal properties, as well as the direct anthropogenic stimulations such as sewage networks and reinjection of thermal waste water, poorly-insulated district heating pipes, especially in built-up areas [3]. A higher subsurface temperature can be expected in urban areas. Subsurface warming has been observed and analysed in several cities at various spatial and temporal scales [4,5]. Taniguchi et al. [4] identified the subsurface warming in Tokyo was $2.8{ }^{\circ} \mathrm{C}$, the strongest among the four cities studied in Asia. One-year measurement of soil 
temperature at rural and urban locations was conducted in Nanjing, China. The urban soil was found $1.21^{\circ} \mathrm{C}$ warmer than the rural soil [6]. Müller et al [7] studied soil temperature ( $<=2 \mathrm{~m})$ at eight locations in the city of Oberhausen, Germany. A maximum SUHI of $9^{\circ} \mathrm{C}$ was found between the city centre station and the rural station. They also pointed out that a high subsurface soil temperature in the city centre had the potential to jeopardize the quality of drinking water from the pipelines. Savva et al [2] measured the daily average soil temperature at a $10-\mathrm{cm}$ depth at both urban and rural sites and found the average annual soil temperature was higher at the urban site. A soiltemperature model was also developed to evaluate the effects of land use changes on soil temperatures. The effects of urbanization on the soil temperature in Ankara were analysed by Turkoglu [8] by comparing paired urban and rural stations. The SUHI was observed higher during night time and lower in the daytime. Yeşilırmak [9] found a general increase of soil temperature in all seasons in Turkey, which was consistent with the increasing trend of air temperature. The highest trend magnitude was $2.05{ }^{\circ} \mathrm{C}$ per decade. Ferguson and Woodbury $[10,11]$ observed that the urban aquifers in urban centre were several degrees $\left(3-5^{\circ} \mathrm{C}\right)$ warmer than those in the surrounding rural area. The SUHI was normally analysed for a short term such as one year, a long term observation is still lacking. Moreover, both climate change and urbanization can affect subsurface temperature, but few studies were able to distinguish them. In the present study, long-term observations (over 100 years) at a remote rural station in the UK were conducted to investigate the effect of climate change on SUHI, furthermore two paired station representing urban and rural characteristics in London were employed to examine the difference of SUHI between urban and rural sites. 
101 The subsurface warming has many potential consequences on such as drinking water

102 quality (1-2m subsurface), groundwater systems at a deeper layer $(100 \mathrm{~m})$ as well as

103 ground thermal energy potential(both shallow and deep layers). Subsurface soil can act

104 as the heat sink in summer and the heat source in winter when being integrated with

105 ground-source heat pumps (GSHP). GSHP is a low-carbon energy-efficient technology

106 for domestic heating and cooling. The performance of the GSHP system is largely

107 determined by the interactions between the heat exchanger and the subsurface soil

108 environment [12]. Therefore, subsurface soil temperature has a predominant influence

109 on the GSHP efficiency such as Coefficient of Performance (COP) $[13,14]$. The subsurface

110 warming will decrease the efficiency for supplying coolness in summer, but enhance the

111 heating performance in winter [15]. Florides et al [16,17] studied the geothermal

112 properties of the ground in Cyprus for a better utilization of GSHP. They concluded that

113 for the same GSHP used, the efficiency of GSHP for heating in Cyprus was higher than

114 that in Germany due to a higher subsurface soil temperature in Cyprus.

115

116 In the UK, it is estimated that the number of installations of GSHP could increase to

11735,000 units by 2015 and 55,000 by 2020 [18]. Approximately $44 \%$ of the total housing

118 stocks are in favour of horizontal ground source heat pump systems due to the lower

119 installation cost with the slinky ground loop or double tier pipe arrangement installed

120 at the shallow sub-ground layers (usually 1-2m in depth)[14] . To our best knowledge,

121 no studies regarding the effects of SUHI on the horizontal GSHP in London, UK, have

122 been carried out so far. Therefore, the present paper serves two aims: 1) to investigate

123 the effect of urbanization and climate change on SUHI in London; 2) to estimate how the

124 SUHI will affect the performance and potential of horizontal GSHP. 


\section{Study sites and data collection}

127 In order to investigate the changes of the subsurface soil temperature in the urban and

128 rural environment in London, two stations with long and continuous observation period

129 were chosen. These stations are provided and affiliated with the British Atmosphere

130 Data Centre (BADC). The paired stations representing urban and rural features are

131 located in the Greater London: St James Park (SJP) in central London and Kenley Airfield

$132(\mathrm{KA})$ in the outskirts of London. As shown in Figure 1, SJP is an urban station $\left(51^{\circ} 30^{\prime} \mathrm{N}\right.$,

$1330^{\circ} 07^{\prime} \mathrm{W}$ ) at an altitude of $5 \mathrm{~m}$, which is only 0.27 miles from Trafalgar Square, the most

134 populated area in central London. The SJP station was built in 1903 and started its

135 operation since 01/01/1959 till present. The station of SJP has been used as an urban

136 station for urban air heat island research in many studies although it was located in an

137 urban park [19-21]. Soil temperature at this station was measured once daily at 9:00pm

138 at 30,50 and $100 \mathrm{~cm}$ depths from 1980 till present. The hourly soil temperature at $10 \mathrm{~cm}$

139 depth was measured since 1999; however, the hourly data were only available from

1402000 to 2007. KA station, which is about 20 miles away from SJP, is located in a rural

141 area to the North West of London $\left(51^{\circ} 18^{\prime} \mathrm{N}, 0^{\circ} 05^{\prime} \mathrm{W}\right)$, at an altitude of $170 \mathrm{~m}$. It

142 commenced on $1^{\text {st }}$ Jan, 1995. Since then, KA station measures hourly soil temperature at

$14310 \mathrm{~cm}$ depth and daily soil temperatures at 9:PM at the depths of 10,30 and $100 \mathrm{~cm}$,

144 respectively. To make it comparable, hourly data from 2000-2007 were collected on

145 both stations for analysis.

146

147 To investigate the effect of climate change on the subsurface soil temperature, another

148 station, Cockley Park (CP), which is located in the county of Northumberland, UK, was

149 chosen. CP is considered to be free of urban influence as shown in Figure 2. It has an

150 altitude of $95 \mathrm{~m}$ between $\mathrm{N} 55^{\circ} 12^{\prime}$ Latitude and $\mathrm{W} 1^{\circ} 41^{\prime}$ Longitude. It was firstly built in 
151 1897, and then operated since 1907. The station recorded daily soil temperatures at

152 different depths at 9:00 PM. But not all depths are recorded every day, only soil

153 temperatures at the depth of $30 \mathrm{~cm}$ were recorded continuously from 1907 to 2011.

154 The data collected from $100 \mathrm{~cm}$ only cover 1907 to 1959, the other depths such as

$15510 \mathrm{~cm}, 20 \mathrm{~cm}$ and $50 \mathrm{~cm}$ are excluded from current study as more than half of the data

156 were missing. Table 1 lists the characteristics of the three stations.

157 The instrument for soil temperature measurement was either Liquid-in-glass

158 thermometer or electrical resistance thermometers suspended at different depths

159 below the ground in a steel tube which was sealed at the surface. The accuracy of the

160 thermometers was below $0.2^{\circ} \mathrm{C}$ which had been validated from the QA lab in Bracknell.

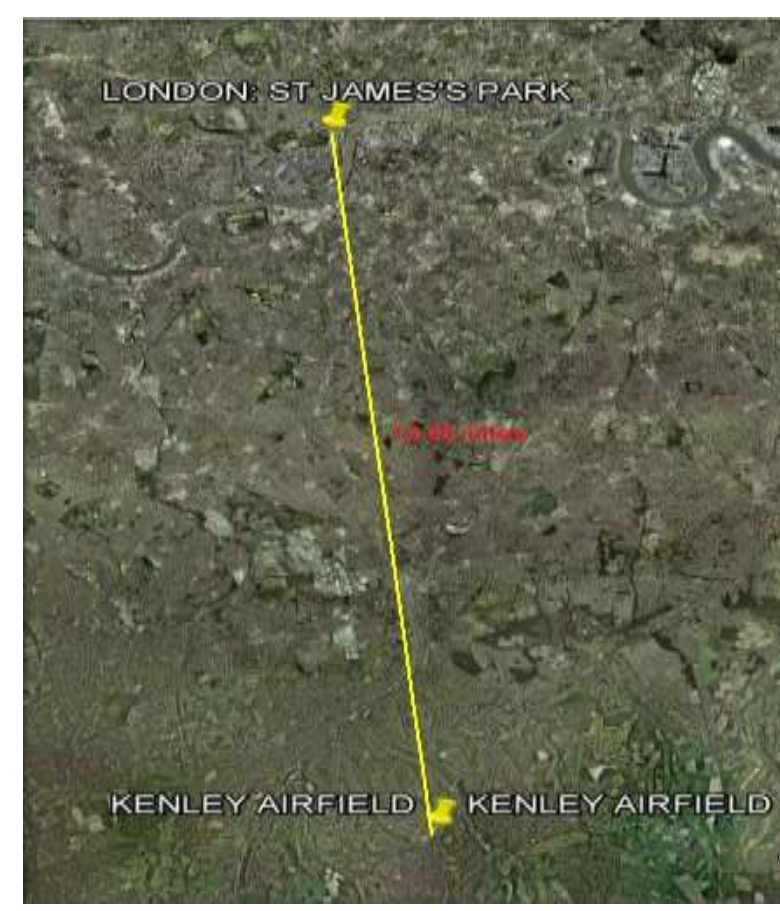

(a)

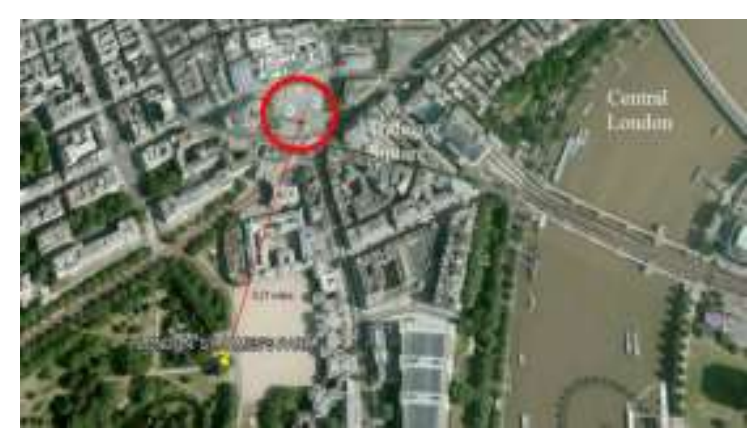

(b)

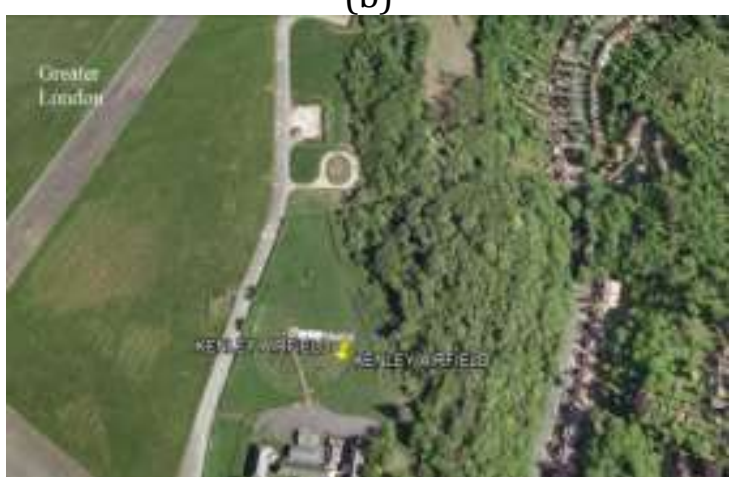

(c)

Figure 1. urban and rural station in Greater London, (a) pair stations on the map with the distance of 14.08 miles; (b) urban characteristics around SJP station; (c) rural characteristics around KA station 


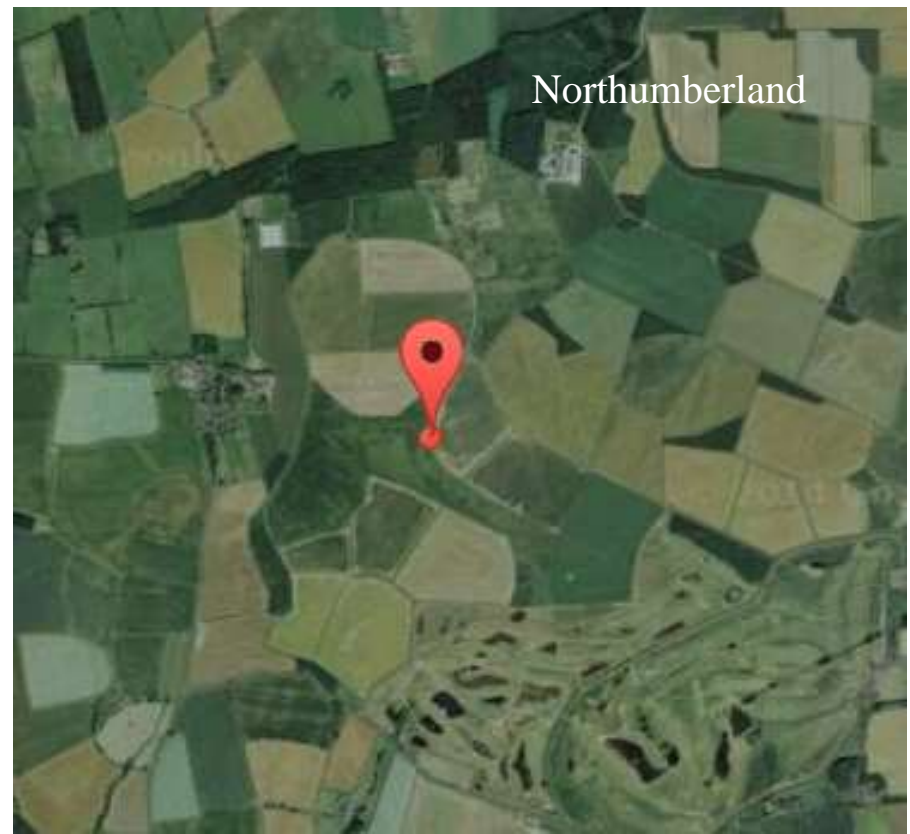

Figure 2: Morpeth: Cockley Park (CP) station which is located in the county of Northumberland, UK, with rural characteristics.

167 Table 1 Three stations for study

\begin{tabular}{|lllll|}
\hline Station & Location & Year & & Measurement frequency and depth \\
\hline & Start & End & \\
\hline $\begin{array}{l}\text { Cockley Park, (CP) } \\
\text { Northumberland }\end{array}$ & Rural & 1907 & 2011 & $\begin{array}{l}\text { Daily: 9:00PM at 10, 20, 30, 50 and 100 } \\
\text { cm; Only 30cm and 100cm are included } \\
\text { in current study. } \\
\text { Hourly: None }\end{array}$ \\
\hline $\begin{array}{l}\text { St James Park, (SJP) } \\
\text { Central London }\end{array}$ & Urban & 1980 & 2012 & $\begin{array}{l}\text { Daily: 9:00PM at 30, 100cm; } \\
\text { Hourly: 10cm from 2000-2007 }\end{array}$ \\
\hline $\begin{array}{l}\text { Kenley Airfield, (KA) } \\
\text { Greater London }\end{array}$ & Rural & 1995 & 2012 & $\begin{array}{l}\text { Daily: 9:00PM at 30, 100cm; } \\
\text { Hourly: 10cm from 2000-2007 }\end{array}$ \\
\hline
\end{tabular}

\section{Results and discussions}

$171 \quad 3.1$ Long-term (100 years) annual mean soil temperature variations

172 The non-parametric Mann-Kendall test was employed to search for trends in soil

173 temperature and Sen's Slope estimator was used to predict the magnitudes of the trends.

174 The similar approaches have been adopted to assess the trend in other time-series 
175 analysis in climatological and hydrologic studies as suggestd by the World

176 Meteorological Organization (WHO) [8,9,26,27]. When a trend exists, the null

177 hypothesis $(\mathrm{HO})$ is rejected ( $\mathrm{H} 0=$ the slope of the regression is zero). The Mann-Kendall

178 tests were performed using XLSTAT 2015. Mann-Kendall test statistics for soil

179 temperature at different depths at different sites are present in Table1. All sites except

180 for KA show a significant warming trend (at 5\% confidence as shown in bold in Table1)

181 at all depths. No significant trend is observed at KA station is partly due to the relatively

182 small number of data available. Annual mean soil temperature data at the depth of

$18330 \mathrm{~cm}$ at the remote rural station of CP from 1907 to 2011 were plotted in Fig.3 (a). Over

184 one hundred years, the increasing rate of soil temperature is $0.17^{\circ} \mathrm{C}$ per decade in $\mathrm{CP}$.

185 Other studies also reported similar results. Changnon [22] observed an increase of 0.67

$186 \mathrm{~K}$ in soil temperature at a depth of $91.5 \mathrm{~cm}$ in Urbana, Illinois, USA, during the period of

187 1903-1947. Yeşilırmak [9] analysed the soil temperature at different depths in Turkey

188 from 1970 to 2006, and found a general positive increasing rate for all seasons and the

189 signal was stronger at upper soil layers. The trend magnitudes were within the

190 spectrum of -0.91 to $2.05^{\circ} \mathrm{C}$ decade ${ }^{-1}$. Carcia-Garcia-Suarez and Bulter [23] reported a

191 soil warming trend within a range of magnituides of 0.04 to $0.25^{\circ} \mathrm{C}$ decade- ${ }^{-1}$ at three

192 stations in Northern Ireland from 1904 to 2002. The annual trends for both $30 \mathrm{~cm}$ and

$193100 \mathrm{~cm}$ depths were $0.13 \mathrm{~K} /$ decade. This is one of very few studies with the similar

194 length of observation duration as ours. Compared with other studies available, our

195 analysis result falls in among them. This trend on soil temperature is also comparable to

196 the annual air temperature trends $\left(0.12-0.14^{\circ} \mathrm{C}\right.$ decade $\left.{ }^{-1}\right)$ from 1931 to 2006 at several

197 stations in and around London [24]. 
199 As the soil temperature at $100 \mathrm{~cm}$ was only available from 1907 to 1959 , a comparison

200 between $30 \mathrm{~cm}$ and $100 \mathrm{~cm}$ can only be made during this period and depicted in Fig.3 (b).

201 Generally, the soil temperature at a deeper depth of $100 \mathrm{~cm}$ is higher than that at $30 \mathrm{~cm}$,

202 but exhibiting a similar increasing rate of $0.15^{\circ} \mathrm{C}$ decade-1. A slightly smaller warming

203 rate of $0.15^{\circ} \mathrm{C}$ decade $^{-1}$ was obtained for soil temperature at $30 \mathrm{~cm}$ at the early half of

204 the $20^{\text {th }}$ century, indicating the climate change became intenser after 1960s. As CP

205 station is located in the rural area which is free of urban influence, the increase of

206 subsurface temperature can be regarded as the sole impact of climate change. The

207 present study showed that the rise in subsurface temperature parallels atmospheric air

208 temperature in the framework of global warming.

209

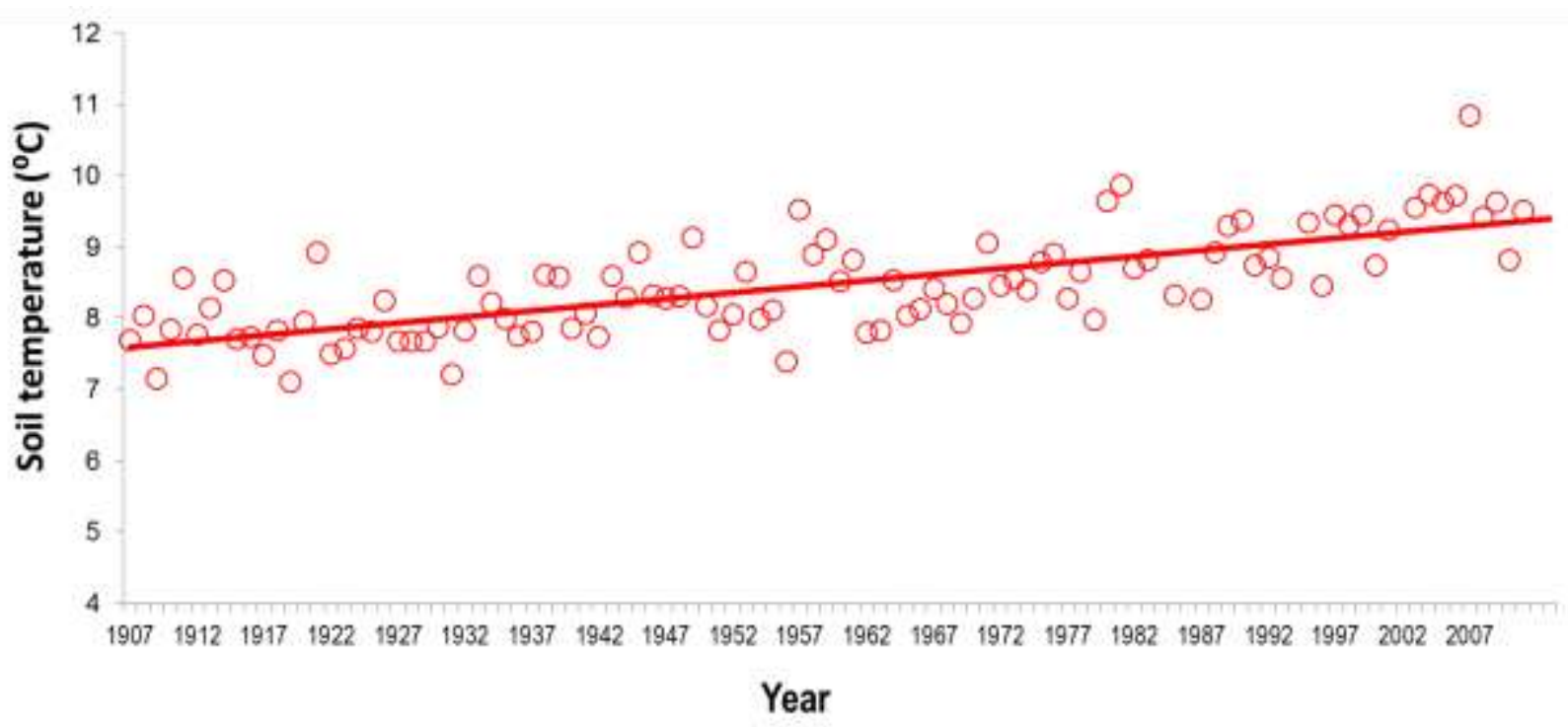

(a) At the depth of 30cm from 1907-2011. 
212

215 Table 1 Mann-Kendall test statistics for soil temperature at different depths at different sites

\begin{tabular}{|lll|}
\hline \multicolumn{1}{|c|}{ Variables } & $\mathbf{Z}$ & Slope $\left({ }^{\circ} \mathrm{C} /\right.$ decade $)$ \\
\hline $30 \mathrm{~cm}$ at CP station (1907-2011) & $\mathbf{8 . 3}$ & 0.17 \\
\hline $100 \mathrm{~cm}$ at CP station (1907-1959) & $\mathbf{3 . 2 8}$ & 0.15 \\
\hline $30 \mathrm{~cm}$ at CP station (1907-1959) & $\mathbf{3 . 4 1}$ & 0.15 \\
\hline $30 \mathrm{~cm}$ at SJP station (1980-2012) & $\mathbf{4 . 3 2}$ & 0.85 \\
\hline $100 \mathrm{~cm}$ at SJP station (1980-2012) & $\mathbf{4 . 6 2}$ & 1.18 \\
\hline $30 \mathrm{~cm}$ at KA station (1994-2012) & 0.56 & 0.26 \\
\hline $100 \mathrm{~cm}$ at KA station (1994-2012) & 1.85 & 0.75 \\
\hline
\end{tabular}
analysed and shown in Fig.4. A much more profound warming trend $\left(1.18^{\circ} \mathrm{C}\right.$ decade ${ }^{-1}$

(b) At the depths of $30 \mathrm{~cm}$ and $100 \mathrm{~cm}$ from 1907 to1959

Figure 3. Annual soil temperature in CP station at 9:00 PM

Z, Mann-Kendall test statistics; slope, Sen's Slope Estimator. Significant trends at 5\% level are shown in bold

\subsection{Urban vs. rural observations}

In order to investigate the urbanization effect, the soil temperature at two depths of $30 \mathrm{~cm}$ and $100 \mathrm{~cm}$ collected from urban and rural stations in London were futher at $100 \mathrm{~cm}$ and $0.85^{\circ} \mathrm{C}$ decade ${ }^{-1}$ at $30 \mathrm{~cm}$ ) is observed in SJP at all depths compared with that at the rural station of KA. The temperature time profile at KA is rather flat and

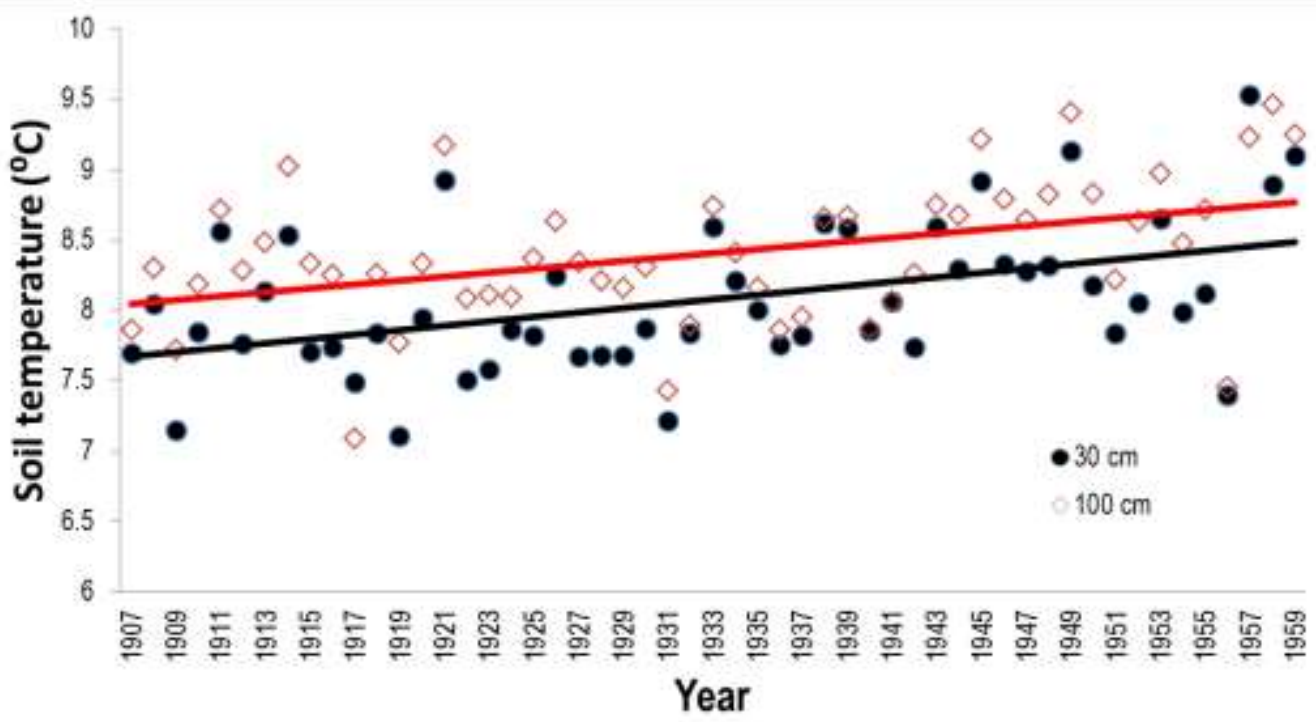


there is no trend observed at 5\% significance level as shown in Table1. The temperature difference between $30 \mathrm{~cm}$ and $100 \mathrm{~cm}$ is not significant at both sites. This rising rate of temperature in urban station is a result of combined effect of urbanization and climate change. By subtracting the temperature increase of $0.17^{\circ} \mathrm{C}$ decade ${ }^{-1}$ due to climate change from the value due to combined effects, the warming rate attributable to urbanization alone can be roughly estimated as $0.7^{\circ} \mathrm{C}$ per decade at $30-\mathrm{cm}$ depth. Therefore, the signal of urbanization preserved in the subsurface soil accounts for almost 5 times of that due to climate change alone previously reported at CP station.

The monthly mean soil temperature at $10 \mathrm{~cm}$ at both stations and the resultant urban heat island intensity (UHII) (difference between urban and rural soil temperature) are shown in Fig.5. Four typical hours per day, i.e., 6:00, 12:00, 18:00 and 24:00 are chosen. Generally, urban soil temperautres are higher than their rural counterparts in all months. The maximum temperature occurred in July or August and minimum soil temperautre was observed in Janary or December at both sites. This shows the similar pattern as monthly air temperature. During warm months, the ground surface temperature is higher than the deep soil temperature due to the strong solar radiation, the heat is conducted from the ground surface to the deeper layers. While in cold winter, the heat condiction direction reverses especially at nighttime or when there is a snow cover.

On the contrary, the SUHII exhibits a typical U-shape, by peaking in cold winter months and valleying in warm summer months. The maximum UHII is $3.5^{\circ} \mathrm{C}$ at $6: 00 \mathrm{AM}$ in December, and the minimum UHII is $0.2^{\circ} \mathrm{C}$ at $18: 00 \mathrm{PM}$ in July. This pattern is totally different from the observation in Ankara,Turkey [8] and Nanjing, China [6]. A higher 
UHII was confirmed in warm seasons compared to cool seasons in Ankara, Turkey (see

251 Fig.2 in [8]), while a 'W-shape' UHII curve was found in Nanjing (see Fig.6 in [6]). This

252 may be due to the different climates and anthropogenic heat patterns in these cities.

253 Both Ankara and Nanjing have a hot summer and cool winter, where cooling in summer

254 predominates building energy consumption compared to winter. Significant anthropogenic heat was released into urban areas in summer periods, which contributes a significant part to the higher urban heat island intensity. In Nanjing, there is few central-controlled heating systems in winter, but the local heating such as airsource heat pump and household gas boiler emerged in recent years. This may explain why there is a slightly higher UHII in winter than the transition periods of spring and

260 autumn in Nanjing. While London in the UK enjoys cool summer and cold winter. Most of building energy is used for space heating in winter, a large contribution of anthropogentic heat released in the urban areas was from heating in winter [25], which may enhance the urban heat island intensity both above and below the ground surface. This echoes a similar monthly UHI pattern of air temperature observed in London.

Subsurface thermal anomalies derived from paired urban and rural observations are

267 directly attributable to two types of controlling parameters including the external meteorological forces acting on the soil-atmosphere interface (solar radiation, air temperature, wind speed etc), and soil thermal properties (heat capacity, thermal conductivity, and moisture content etc). Urbanization alters these parameters by

271 changing the landscape, landuse, surface cover and anthropogenic heat. The replacement of natural landscape with man-made impervous materials in urban area

273 makes it possible to store more heat in the subsurface soil. The extra heat discharge 274 from subsurface infrastructure and heat loss from basement can further elevate the 
275 underground soil temperature. No information about the soil thermal properties of

276 current urban and rural sites is available to allow a further interpretation of the data,

277 but previous study in Nanjing showed a relatively drier soil was observed in urban site,

278 contributing to the higher urban soil temperature[6].

279

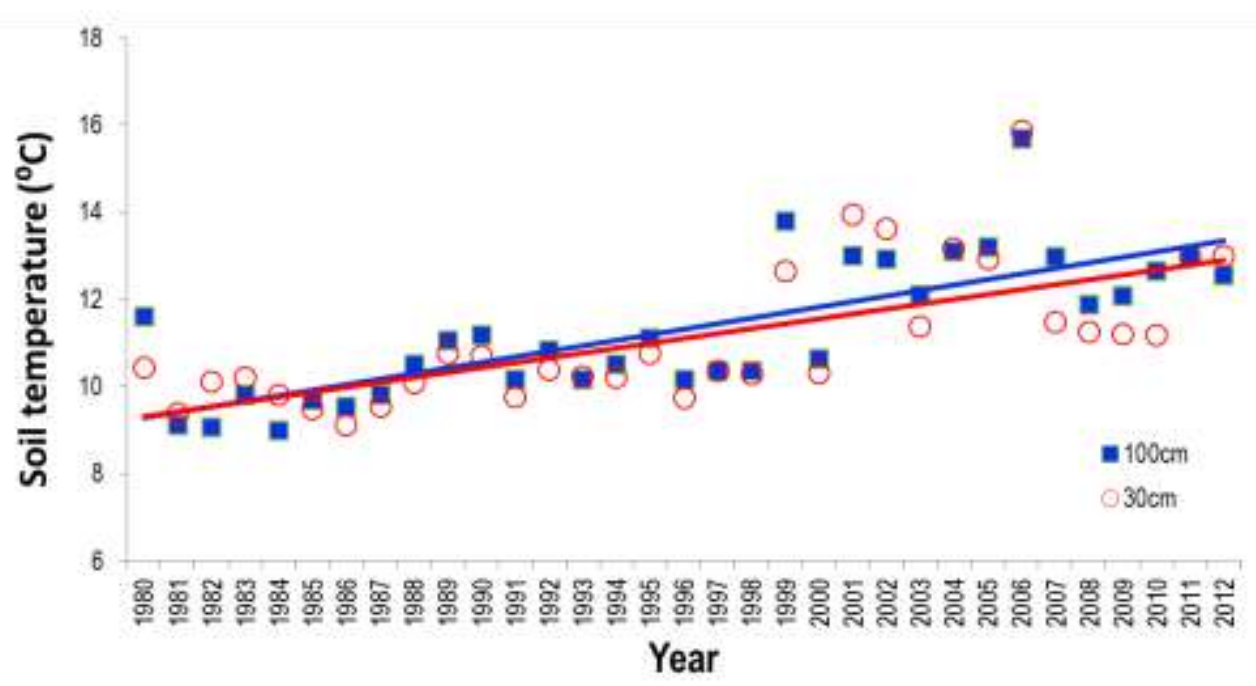

(a) Urban station: SJP

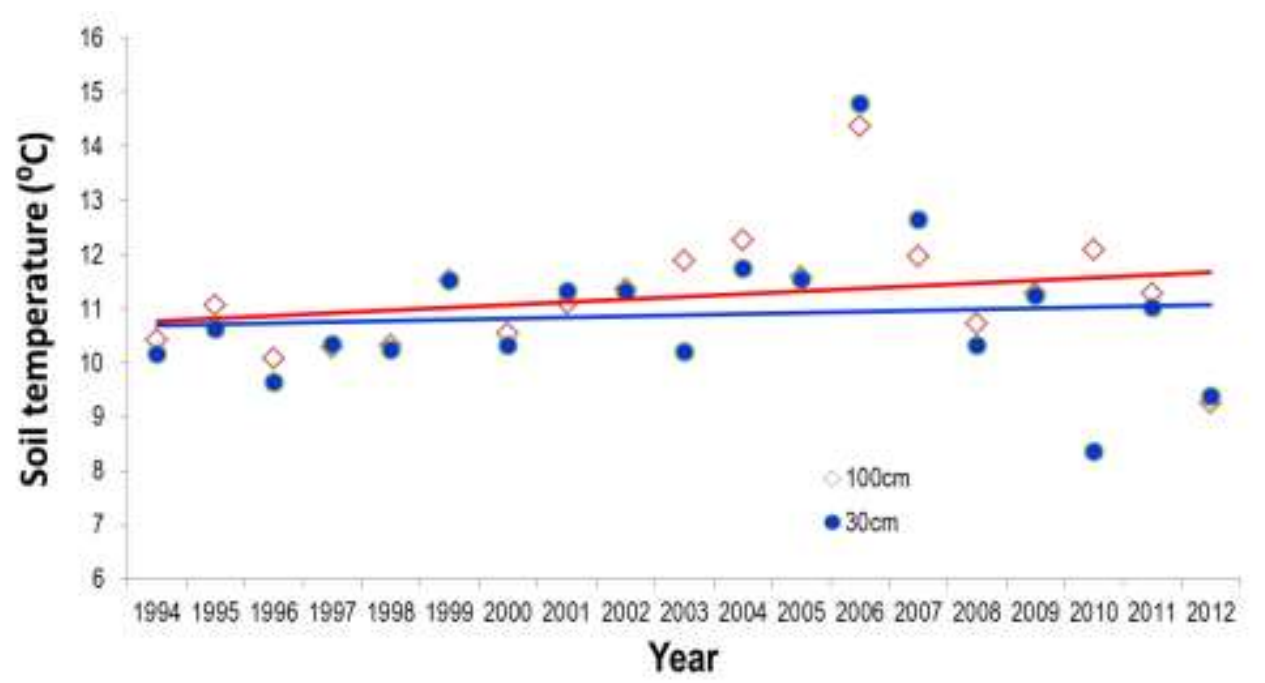

(b) Rural station: KA 
Figure 4. Comparation of yearly soil temperature at depths of 30 and $100 \mathrm{~cm}$ at 9:00 PM between urban and rural stations

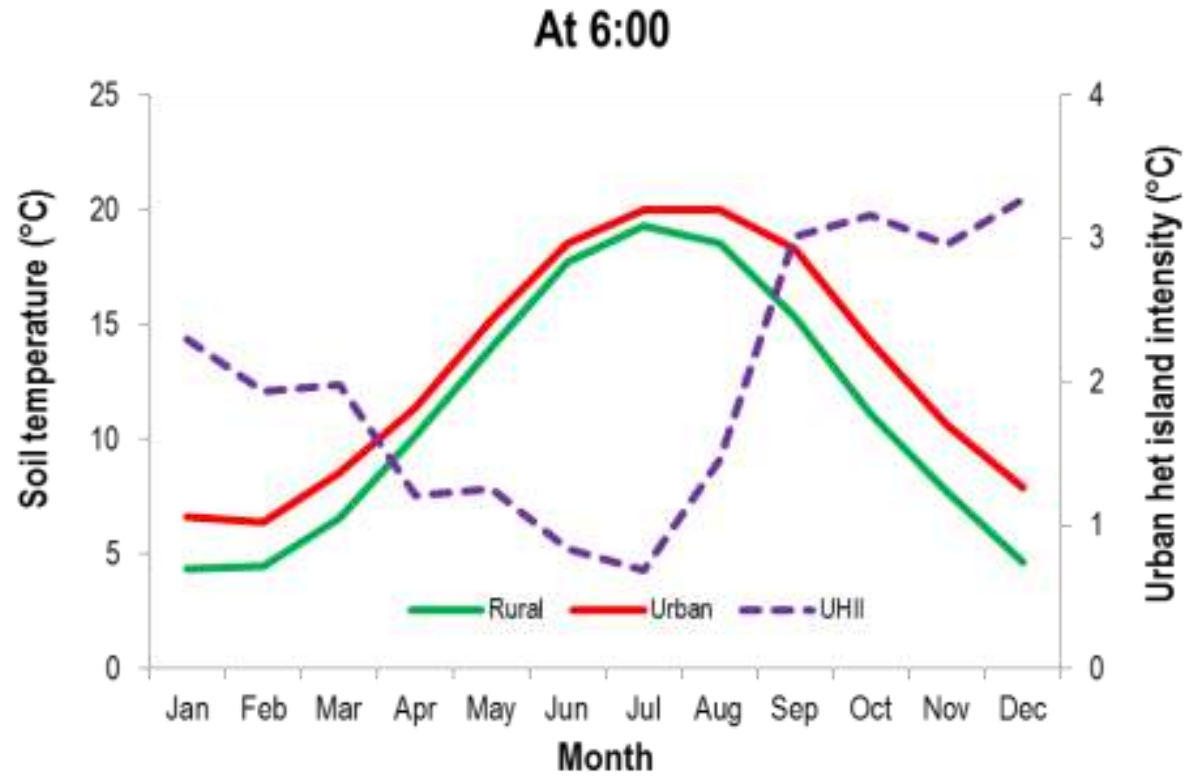

(a) At 6:00

\section{At 12:00}

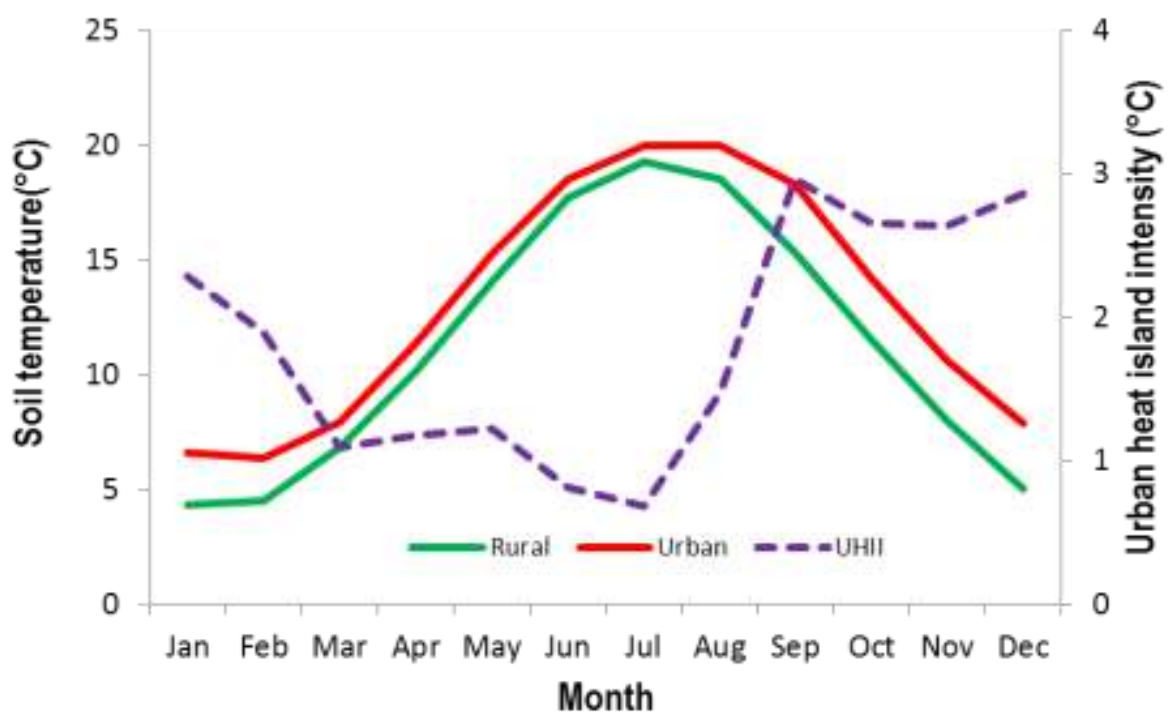

(b) At 12:00 


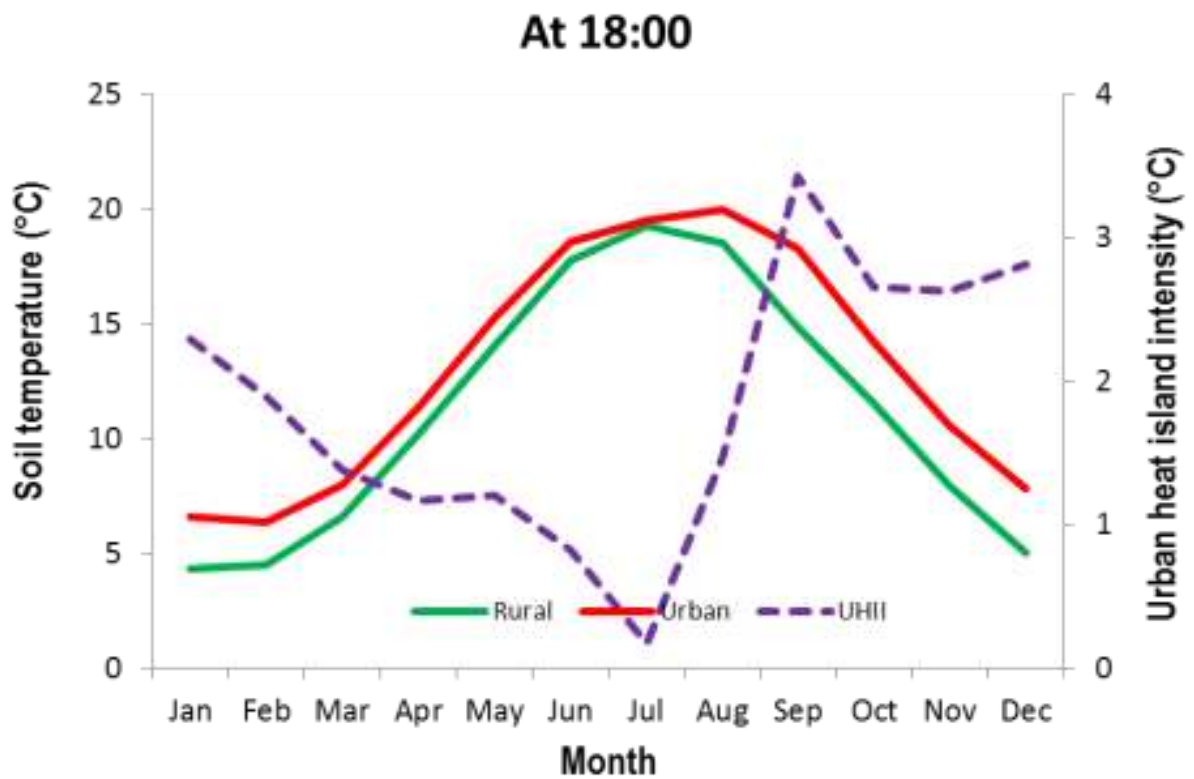

(c) at 18:00

\section{At 24:00}

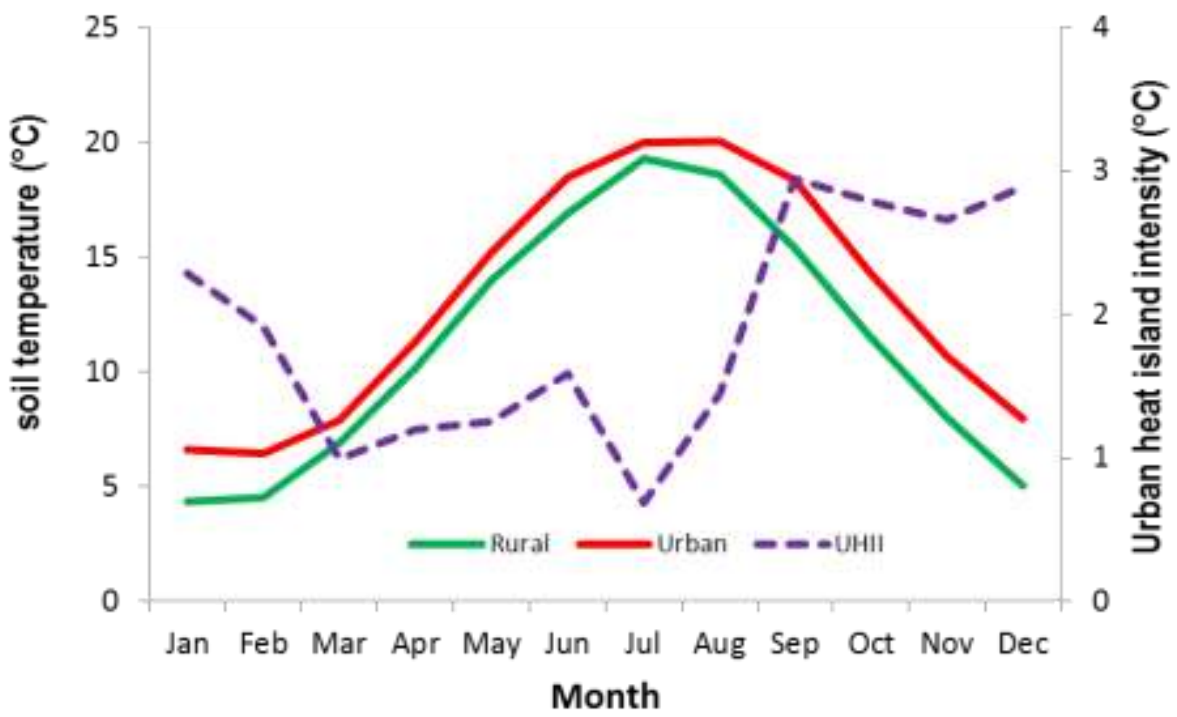

(d) At 24:00

Figure 5 monthly soil temperautre and UHI intensity at $10 \mathrm{~cm}$ at urban and rural stations 
284 The coefficient of performance (COP) of the horizontal GSHP is directly affected by the

285 subsurface soil temperature. Wu et al [14] monitored and measured the performance of 286 a horizontal slinky GSHP for two months in UK. They found the average COP was 2.5 and

287 it decreased with running time as heat was continuously extracted from the soil thermal 288 reservoir. The thermal contrast between urban and rural subsurface will also give rise 289 to the different system performance of horizontal GSHP. The elevated urban soil 290 temperature in winter can improve the COP when GSHP is installed in urban areas.

292 The seasonal variation of SUHI at both urban and rural sites was calculated and shown

293 in Fig.6. SUHI is higher in autumn and winter when the heating is needed. Therefore, 294 the corresponding GSHP COP with respect to the subsurface soil temperature in both 295 urban and rural areas in heating periods can be determined and shown in Fig.7. The 296 relationship curve (black line) was reproduced from Fig.4 in [16]. The orange-filled 297 circles represented the GSHP installed in urban site while the blue-filled circles were the 298 ones in rural site. It shows clearly that in autumn the GSHP COP in urban site is around 2993.3 while that in rural site is about 3.05. In winter, both the GSHP efficiencies are low, 300 but the COP in urban site is still about 0.2 higher than that in rural site. This confirms 301 that, provided the same heat pumps are used, the installation in an urban site will ensure a higher COP for heating than that in a rural site. There are many concerns of the imbalanced heat discharge and storage during the annual operation of GSHP. In warm

304 climate where cooling load is larger than heating load, the heat injected into the ground 305 will be higher than the heat extracted during heating period which gives rise to the 306 decreased working efficiency. This will be exacerbated in urban sites by elevated SUHI.

307 However, for the climate in the UK, where the heating load in winter is predominantly 308 larger than cooling load in summer, SUHI on urban sites will alleviate such imbalance. 
309

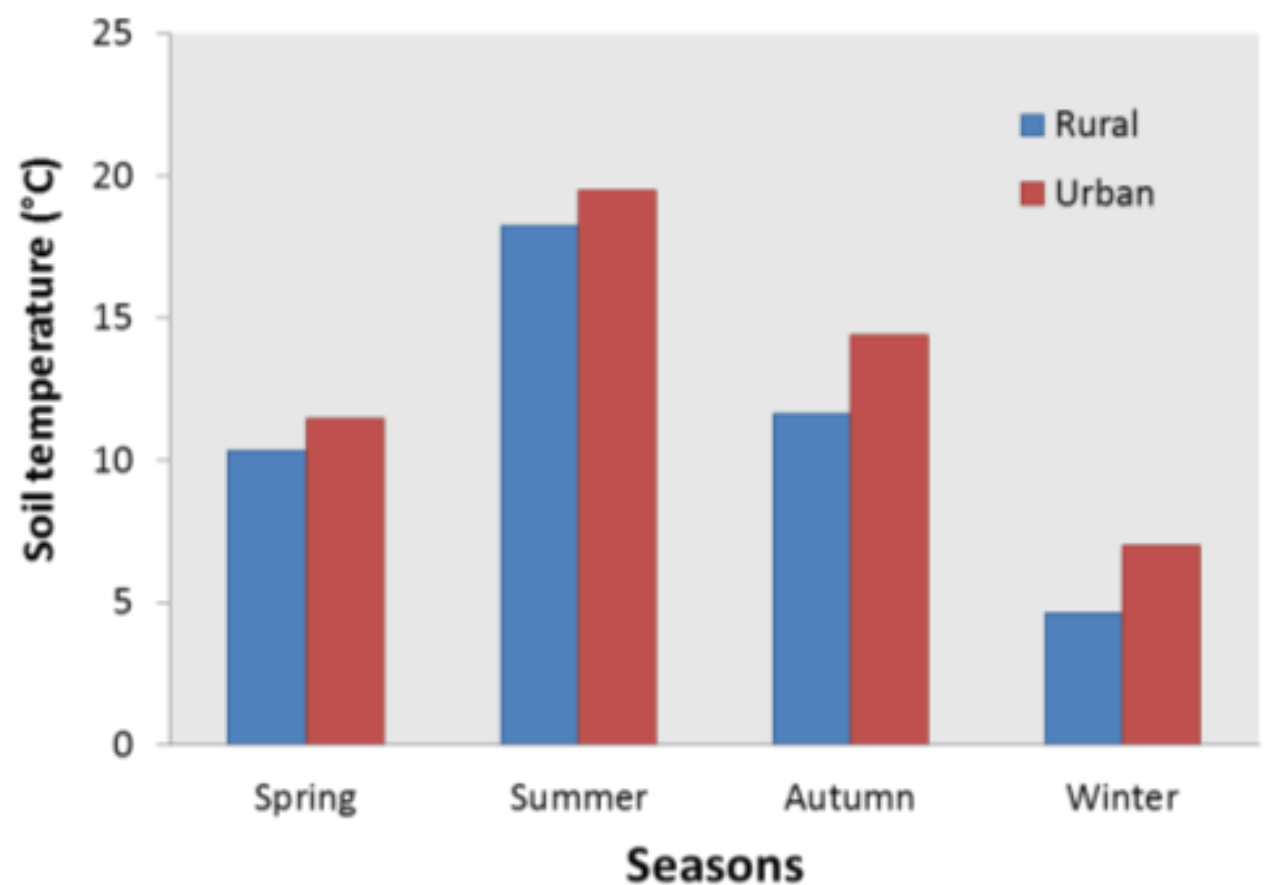

311 Figure 6. Seasonal variation of soil temperature in urban and rural sites

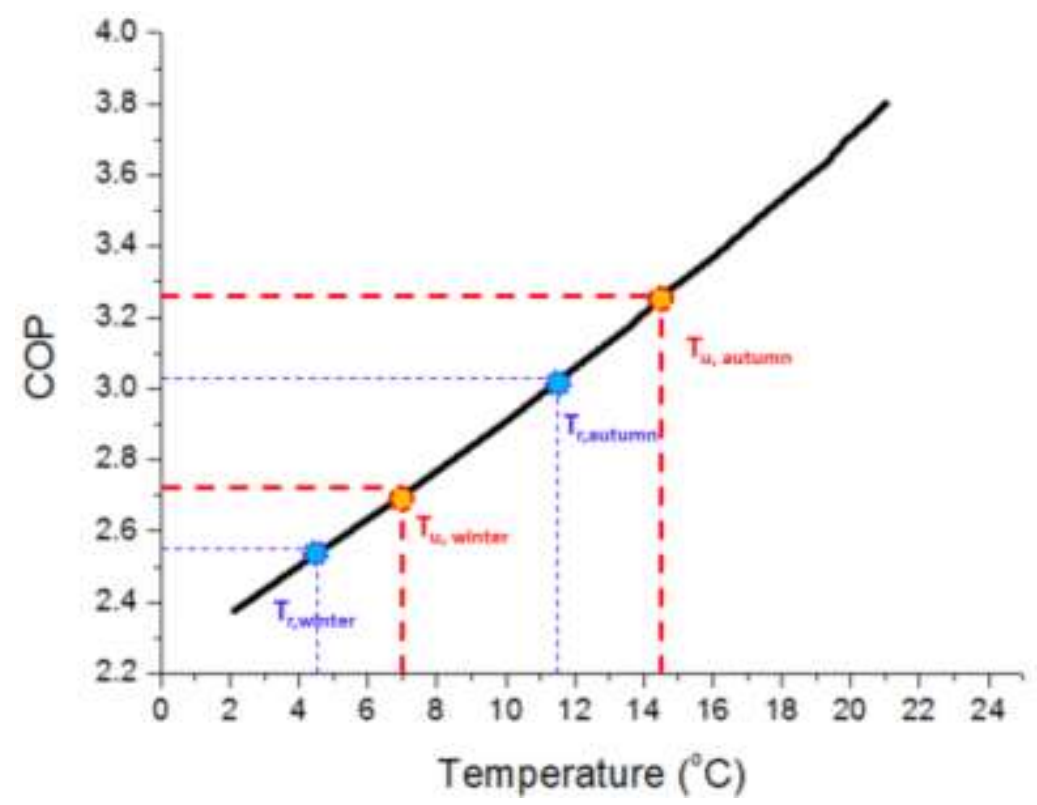

313 Figure 7. GSHP efficiency with respect to subsurface soil temperature (reproduced from

$314 \quad[16])$.

315

316 4. Limitations and future works 
317 Although our paper presents the first study of subsurface urban heat island on

318 horizontal GSHP, it should be noted that it is subject to some limitations and

319 uncertainties: 1) There may be other influential factors contributing to the

320 elevated subsurface soil temperature observed in the urban site, such as permanent

321 local heat sources (heating pipes, heat sources from building basement etc),

322 different soil physical properties; 2) Horizontal ground-source heat pump will be

323 influenced by direct solar gains, which is not considered in the present work and

324 deserves future study. 3 ) Only COP of GSHP is considered in present paper as as it is

325 the most important indicator of the efficiency of GSHP, however, the influence of

326 subsurface urban heat island on the total energy demand can be studied by 327 employing a whole-building energy modelling approach such as Trnsys which we 328 aim to study in the future.

\section{Conclusions}

331 Many studies on urban heat island are devoted to the analysis of the surface and air temperatures, few address the subsurface soil warming. This study analysed the long-term data of subsurface soil temperature observations in three weather stations in the UK. One station located in a remote rural site and free of urban influence contains a long-term measurements over 100 years. Paired urban-rural stations in London were chosen as the hourly soil temperature data were continuously recorded from 2000 to 2007. The characteristics of subsurface warming due to urbanization and climate change were identified. The further effects on the performance of the horizontal ground source heap pump were also evaluated. The following conclusions can be drawn from present study: 
- An increasing rate of $0.17^{\circ} \mathrm{C}$ per decade due to climate change was identified in the UK, but the subsurface warming in an urban site in London shows a much higher rate of $1.18^{\circ} \mathrm{C} /$ decade at the soil depth of $100 \mathrm{~cm}$.

- A positive warming trend of $0.7^{\circ} \mathrm{C} /$ decade at $30-\mathrm{cm}$ depth was regarded to be attributable to urbanization alone, indicating an undeniable global warming effect due to the subsurface urban heat island.

- SUHII in London exhibits an unique 'U-shape', showing lowest in summer and highest during winter. The maximum SUHII is $3.5^{\circ} \mathrm{C}$ at 6:00 $\mathrm{AM}$ in December, and the minimum UHII is $0.2^{\circ} \mathrm{C}$ at $18: 00 \mathrm{PM}$ in July.

- Provided the same heat pump used, the COP is consistently higher in urban sites than that installed in rural sites. The improvement of COP can be as high as $\sim 0.2$ in winter.

- In the climate of UK where the heating load in winter is predominantly larger than cooling load in summer, a larger SUHII during winter time will help to alleviate such imbalance of heat storage and discharge annually by GSHP when the GSHP is installed on urban sites.

\section{Acknowledgments}

The authors would like to thank the financial support from the Key laboratory of the Three Gorges Reservoir Region's Eco-Environment, Ministry of Education, Chongqing University, China, and the Walker Institute Fund in University of Reading, UK. 


\section{References}

363

364

365

366

367

368

369

370

371

372

373

374

375

376

377

378

379

380

381

382

383

384

385

386

387

388

389

390

391

392

393

394

395

396

397

398

399

400

401

402

403

404

405

406

407

408

409

410

[1] T. Oke, Boundary layer climates, 2nd Edition ed., Routledge, 1987.

[2] Y. Savva, K. Szlavecz, R.V. Pouyat, P.M. Groffman, G. Heisler, Effects of Land Use and Vegetation Cover on Soil Temperature in an Urban Ecosystem, Soil Sci. Soc. Am. J., 74 (2010) 469-480.

[3] K. Menberg, P. Blum, A. Schaffitel, P. Bayer, Long-Term Evolution of Anthropogenic Heat Fluxes into a Subsurface Urban Heat Island, Environmental Science \& Technology, 47 (2013) 9747-9755.

[4] M. Taniguchi, T. Uemura, K. Jago-on, Combined Effects of Urbanization and Global Warming on Subsurface Temperature in Four Asian Cities, Vadose Zone J., 6 (2007) 591-596.

[5] F. Perrier, J.L. Le Mouël, J.P. Poirier, M.G. Shnirman, Long-term climate change and surface versus underground temperature measurements in Paris, International Journal of Climatology, 25 (2005) 1619-1631.

[6] C.-S. Tang, B. Shi, L. Gao, J.L. Daniels, H.-T. Jiang, C. Liu, Urbanization effect on soil temperature in Nanjing, China, Energy and Buildings, 43 (2011) 3090-3098.

[7] N. Müller, W. Kuttler, A. Barlag, Analysis of the subsurface urban heat island in Oberhausen, Germany, Climate Research, 58 (2014) 247-256.

[8] N. Turkoglu, Analysis of urban effects on soil temperature in Ankara, Environ Monit Assess, 169 (2010) 439-450.

[9] E. Yeşilırmak, Soil temperature trends in Büyük Menderes Basin, Turkey, Meteorological Applications, 21 (2014) 859-866

[10] G. Ferguson, A.D. Woodbury, Subsurface heat flow in an urban environment, Journal of Geophysical Research: Solid Earth, 109 (2004) B02402.

[11] G. Ferguson, A.D. Woodbury, Urban heat island in the subsurface, Geophysical Research Letters, 34 (2007) L23713.

[12] R. Garcia Gonzalez, A. Verhoef, P.L. Vidale, B. Main, G. Gan, Y. Wu, Interactions between the physical soil environment and a horizontal ground coupled heat pump, for a domestic site in the UK, Renewable Energy, 44 (2012) 141-153.

[13] H. Singh, A. Muetze, P.C. Eames, Factors influencing the uptake of heat pump technology by the UK domestic sector, Renewable Energy, 35 (2010) 873-878.

[14] Y. Wu, G. Gan, A. Verhoef, P.L. Vidale, R.G. Gonzalez, Experimental measurement and numerical simulation of horizontal-coupled slinky ground source heat exchangers, Applied Thermal Engineering, 30 (2010) 2574-2583.

[15] S.A. Kalogirou, G.A. Florides, P.D. Pouloupatis, I. Panayides, J. Joseph-Stylianou, Z. Zomeni, Artificial neural networks for the generation of geothermal maps of ground temperature at various depths by considering land configuration, Energy, 48 (2012) 233-240.

[16] G. Florides, P.D. Pouloupatis, S. Kalogirou, V. Messaritis, I. Panayides, Z. Zomeni, G. Partasides, A. Lizides, E. Sophocleous, K. Koutsoumpas, Geothermal properties of the ground in Cyprus and their effect on the efficiency of ground coupled heat pumps, Renewable Energy, 49 (2013) 85-89.

[17] G.A. Florides, P.D. Pouloupatis, S. Kalogirou, V. Messaritis, I. Panayides, Z. Zomeni, G. Partasides, A. Lizides, E. Sophocleous, K. Koutsoumpas, The geothermal characteristics of the ground and the potential of using ground coupled heat pumps in Cyprus, Energy, 36 (2011) 5027-5036.

[18] E.R.R. BERR Department for Business, Energy Trends, in, 2007.

[19] R.L. Wilby, P.D. Jones, D.H. Lister, Decadal variations in the nocturnal heat island of London, Weather, 66 (2011) 59-64. 
411 [20] D.O. Lee, Urban warming? - an analysis of recent trends in london's heat island,

$412 \quad$ Weather, 47 (1992) 50-56.

413 [21] R.L. Wilby, Past and projected trends in London's urban heat island, Weather, 58 (2003)

414 251-260.

415 [22] S.A. Changnon, Comparison of long-term changes in air and soil temperatures at urbana, 416 illinois, Monthly Weather Review, 92 (1964) 471-473.

417

418

419

420

421

422

423

424

425

426

427

428

429

430

[23] A.M. García-Suárez, C.J. Butler, Soil temperatures at Armagh Observatory, Northern Ireland, from 1904 to 2002, International Journal of Climatology, 26 (2006) 10751089.

[24] P.D. Jones, D.H. Lister, The urban heat island in Central London and urban-related warming trends in Central London since 1900, Weather, 64 (2009) 323-327.

[25] M. Iamarino, S. Beevers, C.S.B. Grimmond, High-resolution (space, time) anthropogenic heat emissions: London 1970-2025, International Journal of Climatology, 32 (2012) 1754-1767.

[26] M.D. Martínez, C. Serra, A. Burgueño, X. Lana, Time trends of daily maximum and minimum temperatures in Catalonia (ne Spain) for the period 1975-2004, International Journal of Climatology, 30 (2010) 267-290.

[27] H. Ozdemir, A. Unal, T. Kindap, U. Turuncoglu, Z. Durmusoglu, M. Khan, M. Tayanc, M. Karaca, Quantification of the urban heat island under a changing climate over Anatolian Peninsula, Theor Appl Climatol, 108 (2012) 31-38.

431

432 